\title{
COVID-19 Diagnostic Testing For All - Using Non-Dilutive Saliva Sample Collection, Stabilization and Ambient Transport Devices
}

Authors: Yuan Carrington ${ }^{\dagger}$, Justin Orlino $^{\dagger}$, Alejandro Romero ${ }^{\dagger}$, Jessica Gustin, Mahssa Rezaei, Elizabeth Greene, Summer Rose, Ramani A. Aiyer, Shanavaz Nasarabadi

Are all affiliated with GenTegra, LLC.

†These authors contributed equally

Corresponding author: Yuan Carrington, sherryc@gentegra.com, 1061 Serpentine Lane, Pleasanton, CA 94566.

The authors competing interests declaration The authors are employees of GenTegra LLC. and hold no interests in any other companies. All authors have completed the ICMJE uniform disclosure form at www.icmje.org/coi disclosure.pdf and declare: all authors had financial support from GenTegra LLC and The National Institute of Health, National Institute of Allergy and Infectious Disease Grant R44Al132032 for the submitted work; no financial relationships with any organizations that might have an interest in the submitted work in the previous three years; no other relationships or activities that could appear to have influenced the submitted work Credits: The chemistry for GTR-STM transport media was developed with support from The National Institute of Health, National Institute of Allergy and Infectious Disease Grant R44Al132032 Author credits: YC, JO, AR, JG, MR, and EG performed the experiments, JO and SN designed the study, SN and SR analyzed the data, SN, YC, MR, and RAA wrote the manuscript, YC, MR, RAA, SN, and SR wrote the supplement.

Acknowledgement: The authors would like to thank Dr. Raymond Lenhoff PhD. (Molecular Virologist, consultant), and Dr. Michael Hogan PhD. (CSO, PathogenDx), and Robert Barrette (VP Business Development, GenTegra LLC) for their insightful comments and edits.

Key words: Saliva, COVID-19, SARS-CoV-2, RT-PCR, transport media, ambient storage, RNA stability

One Sentence Summary 
medRxiv preprint doi: https://doi.org/10.1101/2021.01.20.20243782; this version posted January 25, 2021. The copyright holder for this preprint (which was not certified by peer review) is the author/funder, who has granted medRxiv a license to display the preprint in perpetuity. All rights reserved. No reuse allowed without permission.

GTR-STM and Direct-into-PCR GTR-STMdk offer substantive improvements in SARS-CoV-2 viral RNA stability, safety, and RT-PCR process efficiency for COVID-19 testing by using a non-dilutive saliva sample collection system for individuals at home or onsite respectively. 
medRxiv preprint doi: https://doi.org/10.1101/2021.01.20.20243782; this version posted January 25, 2021. The copyright holder for this preprint (which was not certified by peer review) is the author/funder, who has granted medRxiv a license to display the preprint in perpetuity.

All rights reserved. No reuse allowed without permission.

\section{Abstract}

COVID-19 testing is not accessible for millions during this pandemic despite our best efforts.

Without greatly expanded testing of asymptomatic individuals, contact tracing and subsequent isolation of spreaders remains as a means for control. In an effort to increase RT-PCR assay testing for the presence of the novel beta-coronavirus SARS-CoV-2 as well as improve sample collection safety, GenTegra LLC has introduced two products for saliva collection and viral RNA stabilization: GTR-STM ${ }^{\text {TM }}$ (GenTegra Saliva Transport Medium) and GTR-STMdk ${ }^{\text {TM }}$ (GenTegra Saliva Transport Medium Direct to PCR). Both products contain a proprietary

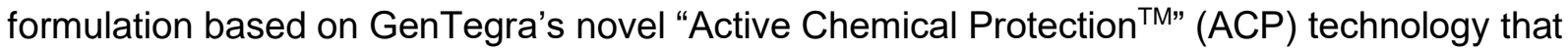
gives non-dilutive, error-free saliva sample collection using RNA stabilization chemicals already dried in the collection tube.

GTR-STM can be used for safer saliva-based sample collection at home (or at a test site).

Following saliva collection, the sample-containing GTR-STM can be kept at ambient temperature during shipment to an authorized CLIA lab for analysis. SARS-CoV-2 viral RNA in GTR-STM is stable for over a month at ambient temperature, easily surviving the longest transit times from home to lab. GTR-STM enhances patient comfort, convenience, compliance and reduces infectious virus exposure to essential medical and lab professionals.

Alternatively, the GTR-STMdk direct-into-PCR product can be used to improve lab throughput and reduce reagent costs for saliva sample collection and testing at any lab site with access to refrigeration. GTR-STMdk reduces lab process time by $25 \%$ and reagent costs by $30 \%$ compared to other approaches. Since GTR-STMdk retains SARS-CoV-2 viral RNA stability for three days at ambient temperature, it is optimized for lab test site rather than at home saliva collection. SARS-COV-2 viral RNA levels as low as 0.4 genome equivalents/uL are detected in saliva samples using GTR-STMdk. The increased sensitivity of SARS-CoV-2 detection can expand COVID-19 testing to include asymptomatic individuals using pooled saliva. 
medRxiv preprint doi: https://doi.org/10.1101/2021.01.20.20243782; this version posted January 25, 2021. The copyright holder for this preprint (which was not certified by peer review) is the author/funder, who has granted medRxiv a license to display the preprint in perpetuity.

All rights reserved. No reuse allowed without permission.

\section{Introduction}

The global COVID-19 pandemic, caused by the novel beta-coronavirus SARS-CoV-2, continues to ravage countries, with the United States bearing the brunt of the attack, and other nations bracing for a second wave (1-3). Testing and contact screening are the primary tools necessary to prevent and contain the infection within communities (4-8).

Rapid strides have been made in advancing molecular and antigen-based testing, which measure viral RNA and surface protein respectively (9-12) for the SARS-CoV-2. Significant progress has been achieved on three fronts, all of which play a significant role in improving patient comfort, patient convenience, and therefore, patient compliance. One major advancement is the shift away from complicated nasopharyngeal (NP) sampling to simpler saliva sampling.

CDC guidance recommends nasopharyngeal (NP) swabs for collection of samples for SARSCoV-2 RT-PCR testing (13). NP sample collection can be uncomfortable, is not suitable for self-collection, and puts the health care professional at risk of infection $(14,15)$. Some of the challenges for collection of NP sample include: (i) Difficulty in collection as the NP probe must be inserted deep into the nostril causing discomfort to the patient and often a gag/cough response. (ii) An element of risk for the trained healthcare professionals authorized to collect the NP sample $(15,16)$. (iii) Shortages in availability of swabs and personal protective equipment for testing, a situation that led to significant under-testing of US populations at risk during the first few months of the pandemic $(17,18)$. (iv) Requiring significant increases in the numbers of trained (currently insufficient) healthcare personnel to staff sample collection sites for testing to expand to mass screening.

In contrast to NP-swabs, saliva is a convenient, safe, and effective sample for SARS-CoV-2 testing, even for children (19-22). This makes it possible to have home saliva collection kits in which patients self-collect the saliva in a sampling tube, which is then mailed to a CLIAcertified laboratory for testing and analysis. Recently, the FDA has approved saliva as an alternate sample for COVID-19 testing (23). Saliva yields diagnostic test results comparable to NP swabs (22). The ease of collection of saliva makes it ideal for the expansion of repeated testing programs in schools, workplaces, and for frequent travelers.

\section{Overview of Existing Saliva Sample Collection and Transport Media Products}

Most saliva sampling and transport media products currently marketed require a two-step process for saliva collection. First, approximately $1 \mathrm{~mL}$ of saliva must be expectorated (spat) 
medRxiv preprint doi: https://doi.org/10.1101/2021.01.20.20243782; this version posted January 25, 2021. The copyright holder for this preprint (which was not certified by peer review) is the author/funder, who has granted medRxiv a license to display the preprint in perpetuity.

All rights reserved. No reuse allowed without permission.

into the sample tube. Second, an additional $1 \mathrm{~mL}$ to $1.5 \mathrm{~mL}$ of a sample-stabilizing liquid, supplied by the manufacturer, must be added to the saliva in the sampling tube (the rationale for this step is to preserve viral RNA integrity, and is discussed in detail in the next section).

The second step above; addition of sample-stabilizing liquid, adds problems that may adversely affect the quality of downstream laboratory results. (i) Reliance on an untrained user to add the secondary liquid introduces the potential for error. If missed, the quality of the sample and therefore the integrity of the test result may be compromised due to viral RNA degradation in transport. (ii) More problematic is the fact that the initial viral load in $1 \mathrm{~mL}$ of collected saliva will be diluted by the additional stabilizing liquid, reducing the detectability of samples with low viral loads, increasing the potential to yield false negative results. (iii) The dilution problem will be particularly acute when mass screenings for SARS-CoV-2 are extended to asymptomatic individuals in schools, workplaces, and to travelers, many of whom may have low or very low levels of virus in saliva. Dilution of these samples by adding a secondary liquid can cause low positive samples to be missed. (iv) The issue of false negative results due to sample dilutive media will also be a severe problem with the adoption of pooled testing, where multiple samples may be combined with a low level positive in a pool, thereby impacting the Limit of Detection (LoD) of the assay.

\section{Assay Sensitivity and False Negative RT-PCR Test Results Due to viral RNA Degradation}

Unlike a DNA sample (such as from a human genome test), which is very stable and maintains its molecular integrity under a variety of harsh conditions, RNA in saliva, which is RNAse-rich, is notoriously unstable and easily degraded. This accounts for the wide variation in test results reported in terms of high false negatives and LoD's. To address this problem, assay protocols typically incorporate two additional steps before starting the PCR reaction. (i) Immediately after sample collection viral RNA stabilization media is added to ensure RNA integrity in the test samples. (ii) An aliquot of the diluted specimen is withdrawn, and the RNA is then subjected to an amplification process to ensure that sufficient quantities are available to serve as a PCR reaction template.

These additional sample treatment steps automatically bring with them more possibilities for error, potentially impacting the quality and accuracy of the test result. The ultimate solution is to find a way to eliminate these steps, by directly adding the undiluted and non-pre-treated saliva to the PCR reaction. 
medRxiv preprint doi: https://doi.org/10.1101/2021.01.20.20243782; this version posted January 25, 2021. The copyright holder for this preprint (which was not certified by peer review) is the author/funder, who has granted medRxiv a license to display the preprint in perpetuity.

All rights reserved. No reuse allowed without permission.

\section{Non-Dilutive Saliva Transport Media, With Less Pre-Analytical Processing Steps}

Two devices that address the limitations of saliva sample collection described above are GTRSTM and GTR-STMdk. They were developed by GenTegra LLC, a Pleasanton, Californiabased company focused on developing products for ambient temperature stabilization and storage of RNA, DNA, proteins, and other biomolecules. The company's Active Chemical Protection $^{\mathrm{TM}}$ (ACP) technology incorporates a proprietary combination of small molecule inhibitors, cytotoxins, antioxidants, metal chelators, and anti-microbials to provide total protection for viral RNA at ambient temperatures. Proprietary ACP chemistry reduces saliva viscosity, inactivates contaminating RNases, and comprises ingredients that inactivate viruses and bacteria. The formulation renders the sample safe for transportation and testing.

Furthermore, ACP is guanidinium-free, which makes it compatible with lab automation and selfsterilizing PCR instrumentation.

Both the GenTegra sample collection devices incorporate a non-dilutive dried media formulation at the bottom of the collection tube that eliminates sample dilution when oral fluid (saliva) is added by simply expectorating into the tube. The ionic and non-ionic denaturants in GTR-STM and the enzymes in GTR-STMdk inactivate the virus by disrupting the lipid envelope of the virus, rendering the saliva safe for transportation and testing. In order to further sterilize the saliva samples, the saliva in both GTR-STM and GTR-STMdk can be heated at $95^{\circ} \mathrm{C}$ for 15 minutes while still maintaining the integrity of the viral RNA for downstream RT-PCR analysis. Unlike EUA-approved home saliva kits available on the market, no additional liquid medium need be added to the saliva sample collected. The dried saliva transport medium in GTR-STM and GTRSTMdk dissolves upon contact with the saliva, thereby stabilizing the viral RNA. GTR-STM and GTR-STMdk makes a more concentrated and more stable RNA sample available for PCR, likely improving the assay LoD.

The distinct features and benefits of the two products are described below.

\section{GTR-STM $^{\text {TM }}$}

- Optimized for home-based saliva sample collection

- For use with legacy high-throughput RT-PCR assay systems, which incorporate an RNA extraction and pre-amplification step 
- Contains a proprietary anti-microbial RNA stabilization formula in dry form, thereby enabling non-dilutive collection of saliva samples eliminating the need for additional liquid media

- Comprises ingredients that inactivate virus in the sample by dissolution and denaturation rendering it safe for transport and testing

- Retains SARS-CoV-2 viral RNA stability with minimal RNA degradation for at least 60 days at ambient temperature

\section{GTR-STMdk ${ }^{\text {TM }}$}

- Optimized for clinical site saliva sample collection that bypasses sample preparation step

- Contains Proteinase $\mathrm{K}$ in a proprietary formulation in dry form, enabling non-dilutive collection of saliva samples and eliminating the need for additional liquid media

- Comprises ingredients that inactivate live virus in the sample, rendering it safe for transport and testing.

- Retains SARS-CoV-2 viral RNA stability with minimal RNA degradation for up to three days at ambient temperature (the time typically required for saliva sample collection and Direct into PCR testing in a lab setting) and up to nine days at $4^{\circ} \mathrm{C}$.

- Improves workflow due to:

- Direct addition of saliva sample to RT-PCR process due to specially modified dry formulation

- Eliminates need for sample pre-extraction step prior to RT-PCR assay, saving $25 \%$ in lab processing time

- Can be used with sample volumes as low as $3.75 \mathrm{uL}$ and $30 \%$ less quantity of RTPCR reagents

- Significant reduction in turnaround times for reporting assay results

- Significant reduction in testing cost by bypassing costs associated with sample extraction

The workflow using GTR-STM is summarized in Figure 1, left side. After saliva samples are received either from test-site or home collection, they are kept at ambient temperature until 
ready to process. They are then disinfected by heating at $95^{\circ} \mathrm{C}$ for 15 minutes in order to further protect lab personnel. The next step is a crucial prerequisite for successful RT-PCR. Aliquots (100 to $400 \mathrm{uL}$ ) of the sample are subjected to extraction using appropriate commercially available reagents (process time = nearly one hour). Then, 3.75 to $5 \mathrm{uL}$ of the extracted RNA sample is amplified in a total reaction volume of $10 \mathrm{uL}$ to $15 \mathrm{uL}$ of RT-PCR mix (process time $=$ nearly one hour) followed by analysis. The entire lab test process including and up to recording of results in the system takes about four hours. (Note: the time from lab workflow process to actual delivery of assay results to patients varies from lab to lab and may take more than 24 hours after sample receipt.)

The workflow using GTR-STMdk is summarized in Figure 1, right side. Here, following saliva collection at the lab, the samples are kept at ambient temperature for 60 minutes to enable complete dissolution of the dried chemicals and activation of pre-dried Proteinase $\mathrm{K}$ (process time $=$ nearly one hour). The samples are then heated for 15 minutes at $95^{\circ} \mathrm{C}$ (process time $=$ nearly 15 minutes). This step will kill any residual Proteinase $\mathrm{K}$ that could potentially interfere with Taq polymerase during RT-PCR and simultaneously disinfect the samples to ensure lab personnel safety. The samples are then cooled at $4^{\circ} \mathrm{C}$ for five minutes before adding directly into the RT-PCR reaction system for assay and analysis (process time = nearly one hour). Since there is $\mathbf{N O}$ extraction and pre-amplification step, the entire process up to recording of results in the system takes about three hours. 


\section{STM}
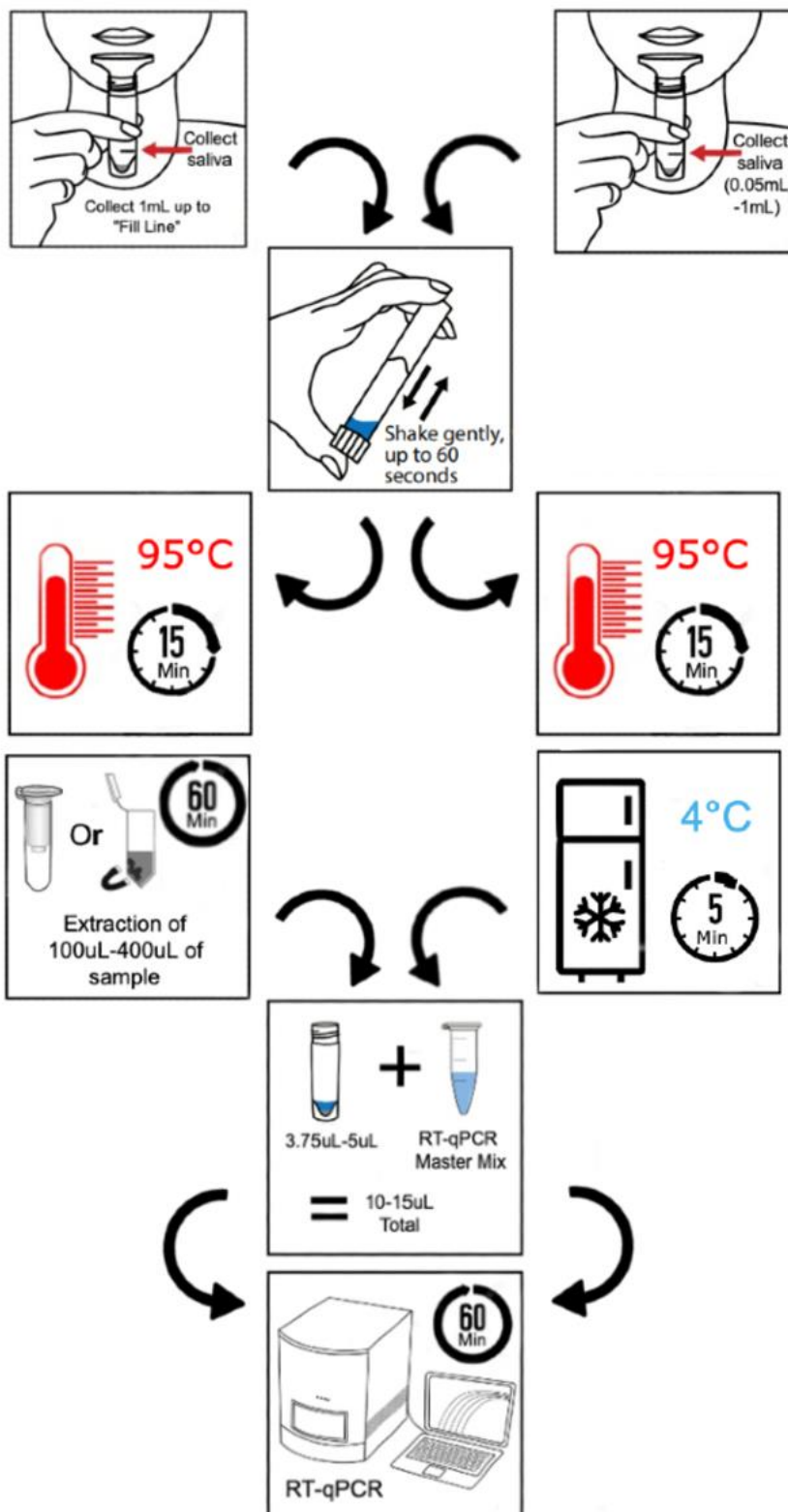

RT-qPCR

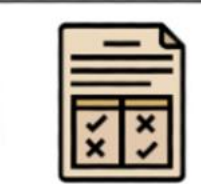

PCR results within 3 hours

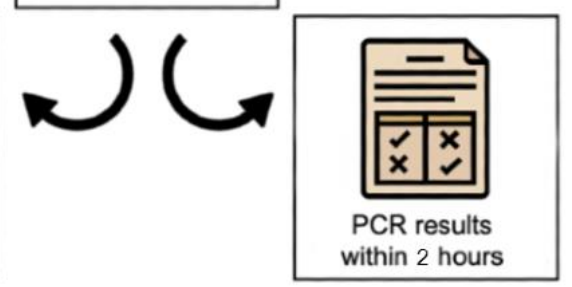

Figure 1: Workflow Comparison SARS CoV-2 RT-PCR Assay of Saliva Samples Collected in GenTegra GTR-STM vs. GTR-STMdk 


\section{Results}

CDC guidelines suggest using N1 and N2 primers for amplification in the RT-PCR assay for SARS-CoV-2. We ran a comparative analysis of N1 and N2 primer data using SARS-CoV-2RNA spiked saliva and established by ANCOVA that the data obtained from either primer (N1 or N2) were statistically equivalent (Supplement S1). Therefore, due to cost and time considerations, all studies reported in this paper (except Figure 6) were performed using only the $\mathrm{N} 1$ primer from CDC.

\section{GenTegra-Saliva Transport Media (GTR-STM) - For Home Saliva/Sputum collection}

Figure 2 compares RT-PCR data of gamma-irradiated SARS-CoV-2 virus spiked in saliva kept in GTR-STM device or non-GTR STM tube ("Saliva”). The data show comparable amounts of RNA are extracted (i.e., equivalent Cycle Threshold [CT] values were obtained) under either conditions.

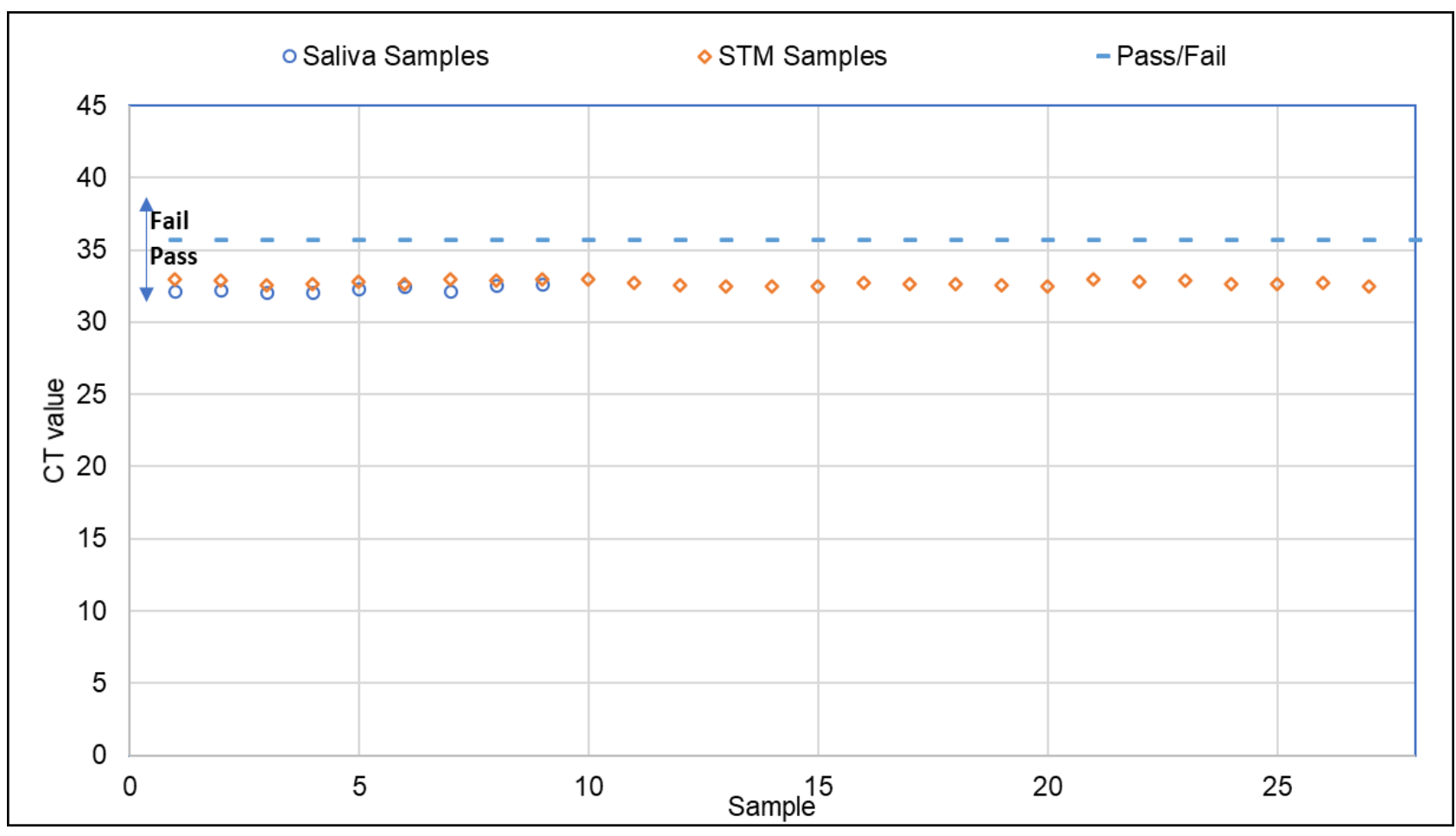

Figure 2: Extraction of Saliva-spiked gamma-irradiated SARS CoV-2 virus: "Saliva" v/s

GTR-STM tubes. Gamma-irradiated SARS-CoV-2 virus (BEI Resources) at 2 genome equivalents/uL was spiked in $1 \mathrm{~mL}$ of saliva kept either in non-GTR STM ("Saliva") (open circles) or GTR-STM devices (open diamonds), extracted with MagMAX Viral RNA Kit (ThermoFisher) and RT$P C R$ performed with CDC's N1 primer. The pass/fail criteria set at 35.7 CT is $3 C T$ values more than the average CT value of the "Saliva" only samples. "Saliva" samples without GTR-STM gave a mean 
medRxiv preprint doi: https://doi.org/10.1101/2021.01.20.20243782; this version posted January 25, 2021. The copyright holder for this preprint (which was not certified by peer review) is the author/funder, who has granted medRxiv a license to display the preprint in perpetuity.

All rights reserved. No reuse allowed without permission.

CT of 32.4 CT (Std Dev, \pm 0.3 ), and Saliva Samples in GTR-STM gave a mean CT of 32.7 CT (Std Dev, $\pm 0.2)$.

\section{Study setup}

Experimental Sample: A contrived GTR-STM sample $(\mathrm{n}=9)$ was prepared by spiking $1 \mathrm{~mL}$ of saliva with 2 genome equivalents/uL of -gamma-irradiated SARS-CoV-2 virus.

Control sample: A contrived non-GTR STM ("Saliva") ( $n=3$ ) sample was prepared by spiking $1 \mathrm{~mL}$ of saliva with 2 genome equivalents/uL of gamma-irradiated SARS-CoV-2 virus.

Sample Extraction: RNA was extracted from $200 \mathrm{uL}$ of sample from both control and stressed samples following manufacturer's instructions for MagMAX Viral RNA (ThermoFisher) manual protocol and eluted with 50uL of elution buffer.

Quantification: Amplify 5uL of extracted RNA from each sample in triplicates with TaqPath master mix (ThermoFisher) and CDC's N1 Primer (IDT).

Saliva has a high concentration of RNase (24). When saliva samples containing SARS-CoV-2 are collected at home and shipped to the remote testing site, there is the likelihood that during transport at ambient temperatures, the viral RNA could be degraded due to exposure to raw saliva. However, the presence of proprietary ACP chemistry in GTR-STM protects and stabilizes the SARS-CoV-2 viral RNA (Figure 3).

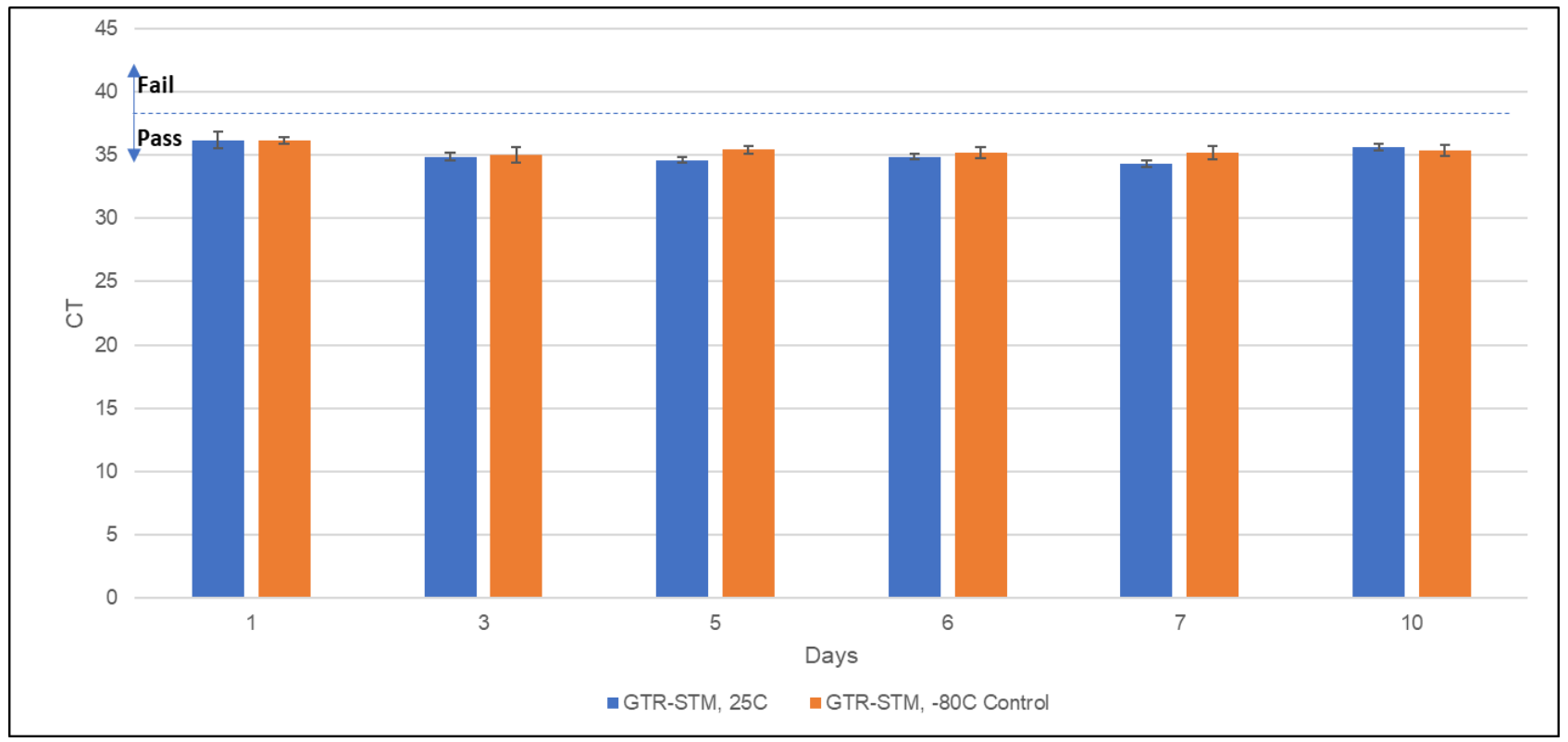

Figure 3: SARS-CoV-2 RNA (NOT whole virus)-spiked Saliva stabilized in GTR-STM ${ }^{\text {TM }}$ for 10 days at ambient temperature $\left(25^{\circ} \mathrm{C}\right) S A R S-C o V-2$ viral RNA (BEI Resources) at 3.0 genome equivalents/uL was spiked into $1 \mathrm{~mL}$ of saliva kept in collection devices with and without GTR-STM, and stored at $25^{\circ} \mathrm{C}$ 
medRxiv preprint doi: https://doi.org/10.1101/2021.01.20.20243782; this version posted January 25, 2021. The copyright holder for this preprint (which was not certified by peer review) is the author/funder, who has granted medRxiv a license to display the preprint in perpetuity.

All rights reserved. No reuse allowed without permission.

for 10 days. Matched spiked control saliva samples were stored at $-80^{\circ} \mathrm{C}$. No viral RNA was extracted from saliva without GTR-STM as the viral RNA is degraded immediately on spiking the saliva with SARS-CoV-2 RNA. Saliva in GTR-STM spiked with viral RNA and stored for up to ten days at $25^{\circ} \mathrm{C}$, yielded $\sim 100 \%$ recovery (Figure 2, blue bars) compared to $-80^{\circ} \mathrm{C}$ control (Figure 2, maroon bars). The pass/fail criteria for saliva in GTR-STM is 38.2 CT. Average CT for control (-80C) GTR-STM samples spiked with SARS-CoV-2 RNA is $35.2 \pm 0.4$ and 36.6 \pm 0.3 for GTR-STM saliva samples spiked with SARS-CoV-2 RNA stressed at $25^{\circ} \mathrm{C}$.

\section{Study setup}

Experimental Sample: $1 \mathrm{~mL}$ of Saliva sample added to dry GTR-STM + 3.0 geq/uL of SARS-CoV-2 viral RNA (BEI Resources). The viral RNA-containing saliva sample was incubated at $25^{\circ} \mathrm{C}$ for up to 10 days.

Control sample: $1 \mathrm{~mL}$ of RNAsecure water spiked with $3.0 \mathrm{geq} / \mathrm{uL}$ viral RNA and stored at $-80^{\circ} \mathrm{C}$.

Sample Extraction: RNA was extracted from 100uL of experimental \& control samples with QIAamp Viral RNA kit and eluted with 100uL of elution buffer.

Quantification: 5uL of RNA was quantified with CDC's SARS-CoV-2 RT-qPCR assay for N1 primer.

The stability studies were further extended using heat-inactivated whole SARS-CoV-2 virus (sourced from BEI resources) spiked into saliva in GTR-STM. When spiked into saliva with GTR-STM, the heat-inactivated SARS-CoV-2 virus was stable for up to 36 days at $25^{\circ} \mathrm{C}$, and up to seven days at $56^{\circ} \mathrm{C}$, prior to RNA extraction and RT-qPCR analysis (Figures 4 and 5). 


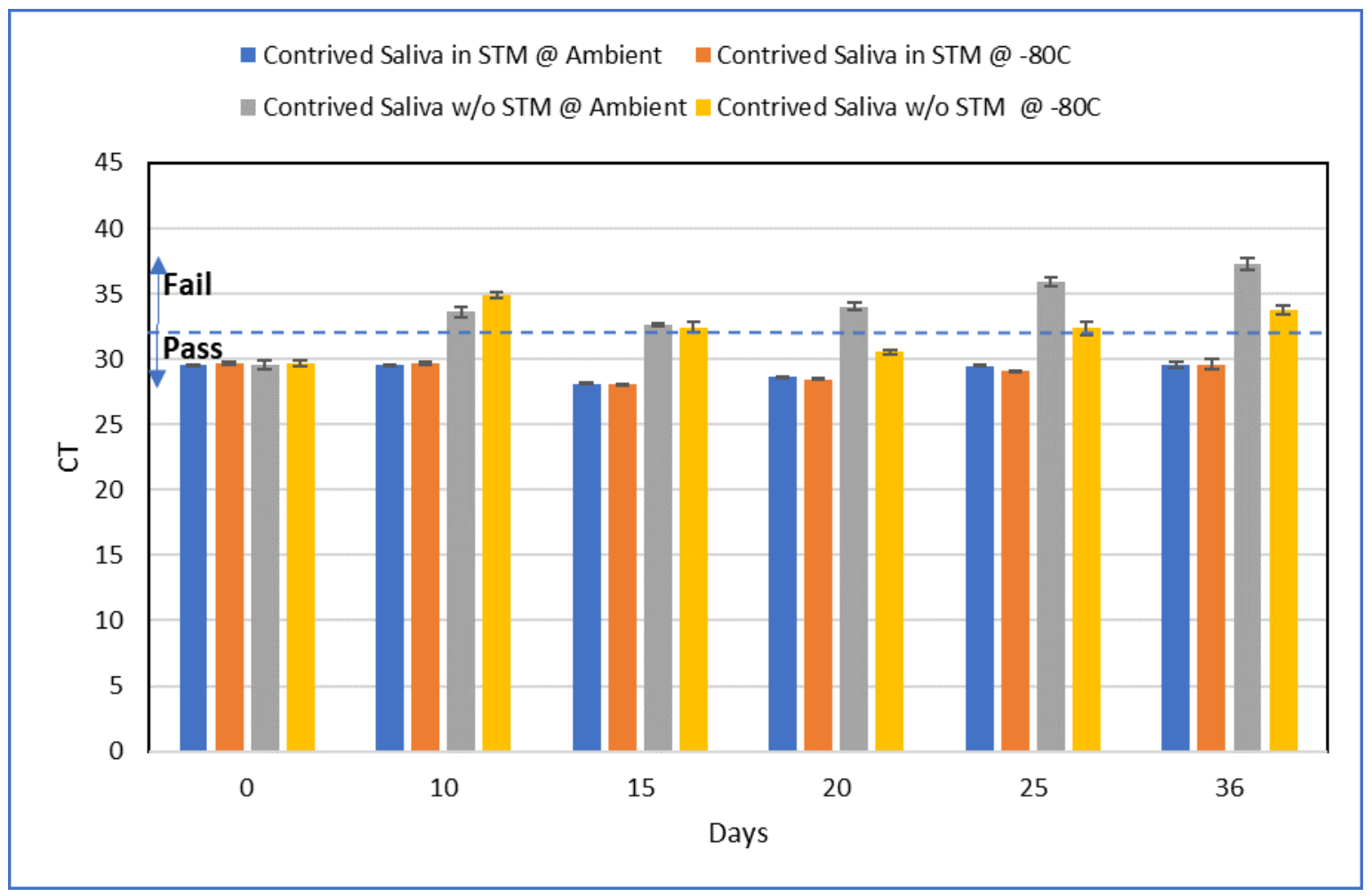

Figure 4: Stability of Saliva-spiked heat inactivated SARS CoV-2 virus stored in GTR-STM devices vs non-GTR-STM ("Saliva") tubes at $25^{\circ} \mathrm{C}$. Heat-inactivated SARS-CoV-2 virus RNA (BEI Resources) at 500 genome equivalents/uL was spiked into $1 \mathrm{~mL}$ of saliva kept either in GTRSTM collection devices or non-GTR-STM ("Saliva”) tubes, and stored at $25^{\circ} \mathrm{C}$ for 36 days. Matched spiked control saliva samples in both kinds of tubes were stored at $-80^{\circ} \mathrm{C}$. The pass/fail criteria are set at 32 CT value. $200 \mathrm{uL}$ of the sample is used at each time point to extract viral RNA with the MagMAX kit with a final elution volume of 50uL. The CT value of the viral RNA extracted with MagMAX viral RNA kit is normalized to input volume of 200uL (volume of sample used for RNA extraction). All GTR-STM samples gave excellent recoveries when compared to their matched $-80^{\circ} \mathrm{C}$ control. Both the $-80^{\circ} \mathrm{C}$ and the $25^{\circ} \mathrm{C}$ samples for the non-GTR-STM ("Saliva") is above the pass/fail line even in the $-80^{\circ} \mathrm{C}$ control samples indicating that the viral RNA is degraded by the Rnase in the short time (less than half hour) that the saliva sample is defrosting before RNA extraction is performed.

\section{Study setup}

Experimental Samples: $1 \mathrm{~mL}$ aliquots of saliva contrived with SARS-CoV-2 at 500 genome equivalents/uL (BEI Resources) were placed into either GTR-STM devices or non-GTR-STM (“Saliva”) tubes and stored at ambient $\left(25^{\circ} \mathrm{C}\right)$ for up to 36 days. 
medRxiv preprint doi: https://doi.org/10.1101/2021.01.20.20243782; this version posted January 25, 2021. The copyright holder for this preprint

(which was not certified by peer review) is the author/funder, who has granted medRxiv a license to display the preprint in perpetuity.

All rights reserved. No reuse allowed without permission.

Control sample: $1 \mathrm{~mL}$ aliquots of saliva contrived with SARS-CoV-2 at 500 genome equivalents/uL (BEI Resources) were placed into either GTR-STM devices or non-GTRSTM ("Saliva") tubes and stored at $-80^{\circ} \mathrm{C}$ for up to 36 days.

Sample Extraction: RNA extracted from 200uL of experimental and control samples with MagMAX viral RNA kit at days 10, 15, 20, 25, and 36 and eluted in 50uL of elution buffer. Quantification: 5uL of RNA was quantified with CDC's SARS-CoV-2 RT-qPCR assay for N1 primer.

SARS-CoV-2 virus samples stored in GTR-STM retained original viral RNA integrity (CT levels below the "Pass/Fail" level) for up to 36 days at ambient temperature, and the CTs values were comparable to controls stored at $-80^{\circ} \mathrm{C}$ (Figure 4). In stark contrast, the samples stored in nonGTR-STM ("Saliva") tubes did not meet the "Pass/Fail" CT level criterion at day 10 at ambient or on subsequent days. The ambient stability difference between GTR-STM and non-GTRSTM ("Saliva") samples was shown to be statistically significant by ANCOVA (Supplemental Data, S2).

Surprisingly, under non-GTR-STM ("Saliva”) storage, even the $-80^{\circ} \mathrm{C}$ stored samples showed inconsistent retention of CT levels below "Pass/Fail." It is likely that in these frozen samples, SARS-CoV-2 viral RNA degradation occurred even during the very short five-minute thaw at $4^{\circ} \mathrm{C}$ prior to $\mathrm{RT}$-PCR.

Figure 5 shows an accelerated stability study by storing samples at an elevated temperature of $56^{\circ} \mathrm{C}$. 


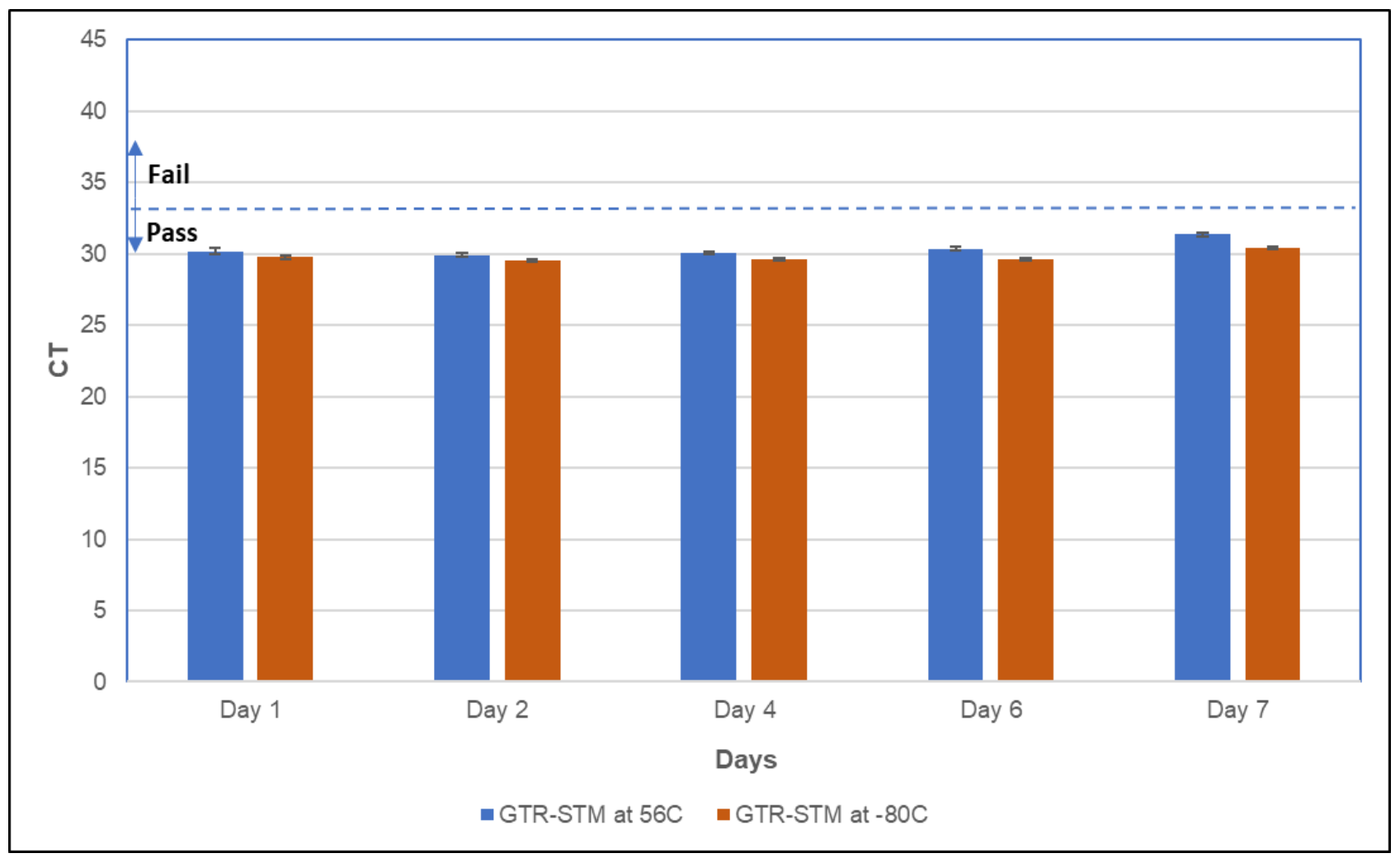

Figure 5: Stability of Saliva-spiked heat inactivated SARS CoV-2 virus in GTR$\mathrm{STM}^{\mathrm{TM}}$ at $56^{\circ} \mathrm{C}$. Heat inactivated SARS-CoV-2 viral RNA (BEI Resources) at 900 genome equivalents/uL was spiked into $1 \mathrm{~mL}$ of saliva kept in collection devices with and without GTRSTM, and stored at $56^{\circ} \mathrm{C}$ for seven days. Matched spiked control saliva samples were stored at $80^{\circ} \mathrm{C}$. The pass/fail criteria is set at $32 \mathrm{CT}$ values.

\section{Study setup}

Experimental Sample: $1 \mathrm{~mL}$ of saliva samples contrived with $900 \mathrm{geq} / \mathrm{uL}$ of heat inactivated SARS-CoV-2 Virus (BEI Resources) were stored in GTR-STM devices. The samples were incubated at $56^{\circ} \mathrm{C}$ for up to 7 days.

Control sample: $1 \mathrm{~mL}$ of saliva samples contrived with $900 \mathrm{geq} / \mathrm{uL}$ of SARS-CoV-2 Virus (BEI Resources) were stored in GTR-STM devices at $-80^{\circ} \mathrm{C}$.

Sample Extraction: RNA was extracted from 100uL of experimental and control samples with QIAamp Viral RNA kit and eluted in 100uL of elution buffer.

Quantification: 5uL of RNA was quantified with CDC's SARS-CoV-2 RT-qPCR assay for N1 primer.

Heat inactivated SARS-CoV-2 virus spiked saliva in GTR-STM retained its stability for up to seven days in GTR-STM. The data show indistinguishable CT values between samples stored 
at $56^{\circ} \mathrm{C}$ and $-80^{\circ} \mathrm{C}$, with all $\mathrm{CT}$ levels below the "Pass/Fail" criterion. This $56^{\circ} \mathrm{C}$ stability for seven days implies equivalent temperature stability at ambient $\left(25^{\circ} \mathrm{C}\right)$ for stored samples of approximately 60 days, based on the Arrhenius equation for temperature dependence of reaction rates. Regression analysis performed (t-statistic test, $\mathrm{P}<0.05$, $\mathrm{R}$-squared value 0.625) based on the seven days data suggests that saliva containing SARS-CoV-2 virus collected in GTR-STM potentially be extrapolated to show stability at ambient temperature more than 214 days (Supplemental Data, S3).

The stability data in Figures $\mathbf{4}$ and $\mathbf{5}$ demonstrate the utility of GTR-STM as a saliva sample collection device in a home setting, allowing for sufficient time from collection, shipping/transportation, and RT-PCR assay under highly variable temperature conditions. Even though GTR-STM media contains components known to inactivate SARS-CoV-2, to ensure an added measure of safety of lab personnel, incoming sample specimens must be pre-heated at $95^{\circ} \mathrm{C}$ for $15-30$ minutes to inactivate any residual live SARS-Cov-2 that may be present $(25,26)$. Figure 6 shows that SARS-CoV-2 viral-spiked saliva samples in GTR-STM can be preheated at $95^{\circ} \mathrm{C}$ for up to 30 minutes prior to RT-PCR without adversely affecting assay sensitivity.

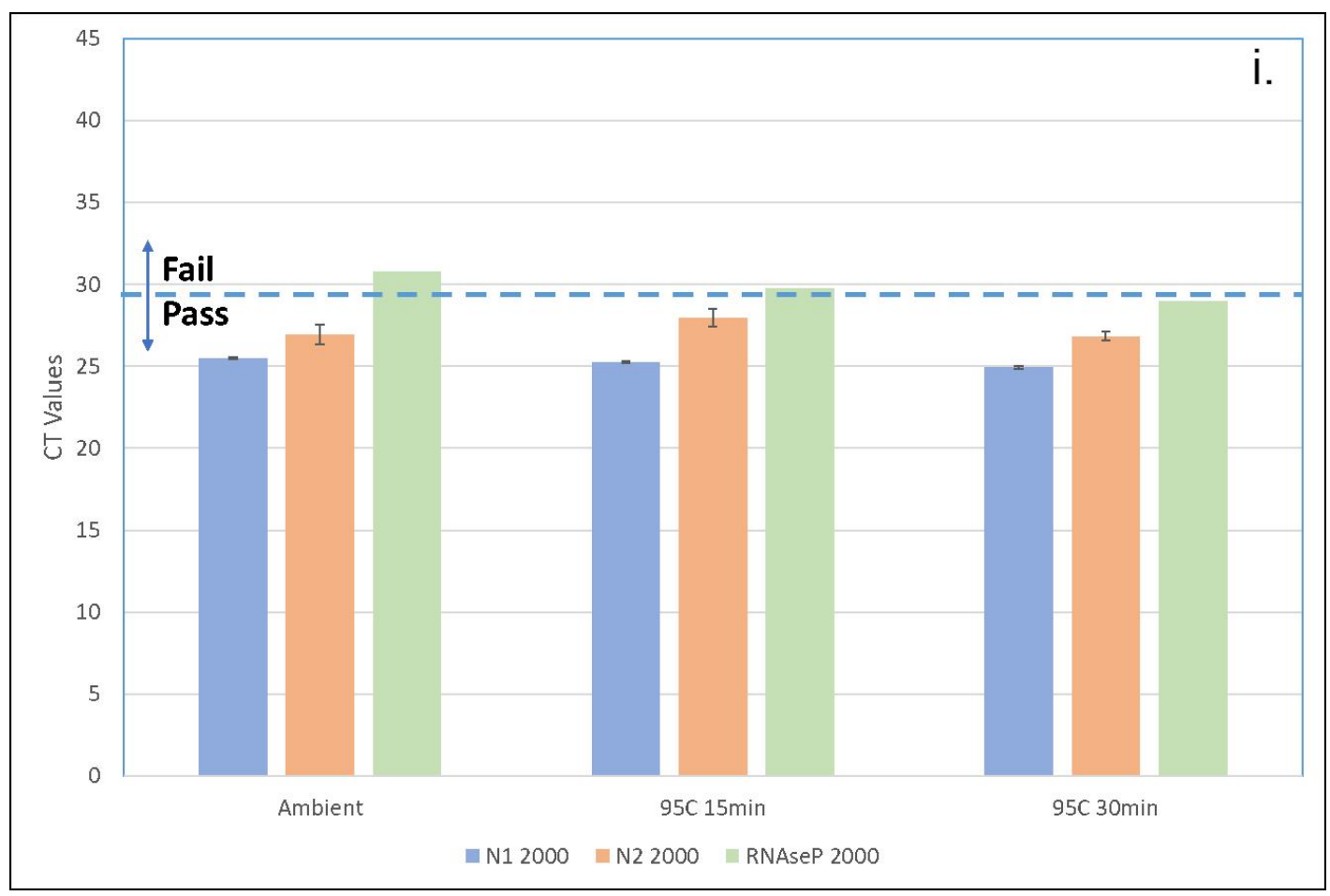




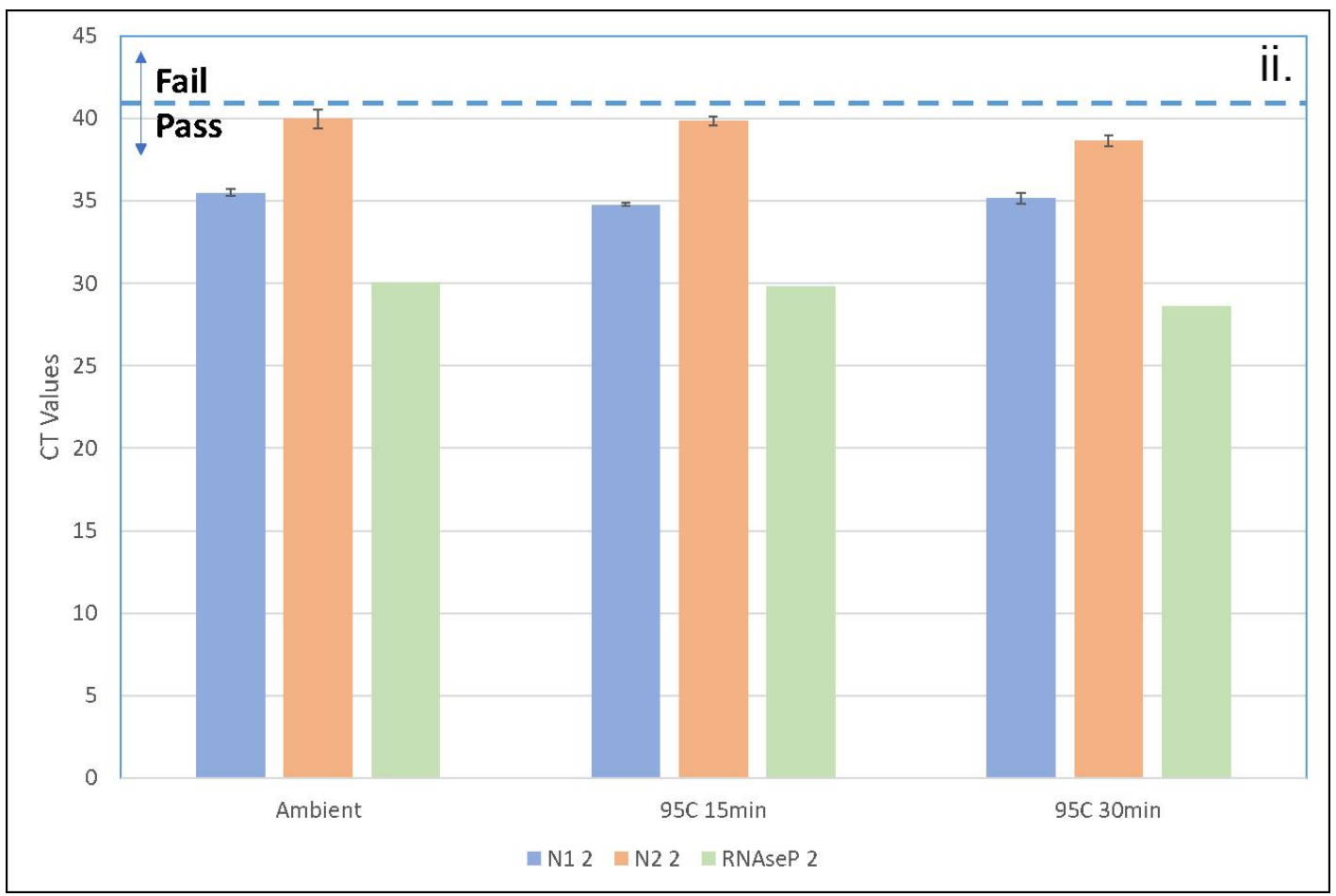

Figure 6: Effect of disinfection of gamma-irradiated SARS-CoV-2 spiked saliva samples collected in GTR-STM by preheating at $95^{\circ} \mathrm{C}$. Gamma-irradiated SARS-CoV-2 virus (BEI

Resources) at 2,000 (i.) and 2.0 (ii.) genome equivalents/uL was spiked in $1 \mathrm{~mL}$ of saliva kept in GTR-STM, and heated at $95^{\circ} \mathrm{C}$ for up to 30 minutes. Matched spiked control saliva samples were kept at ambient temperature. The viral RNA was extracted with QIAamp Viral RNA Mini Kit and quantified with all three $C D C$ primers, N1, N2 and RNase $P$. The pass/fail criteria of $29.22 C T$ values for 2,000 genome equivalent/uL and $40.74 \mathrm{CT}$ values for 2.0 genome equivalents/uL were computed from the average of both $\mathrm{N} 1$ and $\mathrm{N} 2$ primers only at ambient temperature and not for RNaseP.

\section{Study setup}

Experimental Samples: Saliva sample was contrived with 2,000 and 2.0 geq/uL gammairradiated SARS-CoV-2 virus per uL. $1 \mathrm{~mL}$ each of contrived samples were added to GTR$\mathrm{STM}$, heated at $95^{\circ} \mathrm{C}$ for up to 30 minutes.

Sample Extraction: RNA was extracted from 50uL of sample with QIAamp viral RNA kit and eluted in 50uL of elution buffer.

Quantification: 5uL of RNA was quantified by CDC's N1, N2 and Rnase P primer sets.

The data in Figure 6 showed that pre-heating of viral samples for 15 minutes or up to 30 minutes at $95^{\circ} \mathrm{C}$ gave CT values that were consistent with ambient samples using CDC's $\mathrm{N} 1$, $\mathrm{N} 2$ or Rnase $\mathrm{P}$ primers for quantification. The N2 primer yielded higher CT values than N1. 
medRxiv preprint doi: https://doi.org/10.1101/2021.01.20.20243782; this version posted January 25, 2021. The copyright holder for this preprint (which was not certified by peer review) is the author/funder, who has granted medRxiv a license to display the preprint in perpetuity.

All rights reserved. No reuse allowed without permission.

Perhaps the N1 primer binds to a more stable section of the SARS-CoV-2 viral RNA and therefore could be better suited to obtain greater sensitivity in RT-PCR testing for COVID-19.

All the above results (shown in Figures 2 - 6) clearly establish that GTR-STM is a valuable home saliva sample collection device since it (i) retains SARS-CoV-2 activity for 36 days at ambient temperature following sample collection and transportation to a testing lab, (ii) retains SARS-CoV-2 activity for up to seven days at $56^{\circ} \mathrm{C}$, which translates to approximately 60 days at ambient temperature, (iii) can withstand heating conditions up to $56^{\circ} \mathrm{C}$ that may be encountered perhaps unexpectedly at transit points during shipping, and (iv) maintains viral RNA stability during disinfection by heating for up to 30 minutes at $95^{\circ} \mathrm{C}$.

\section{GenTegra-Direct into PCR Media (GTR-STMdk) - For Lab Saliva/Sputum collection in Clinical Diagnostics Laboratory Settings}

While the GTR-STM device solves the problem of dilution described earlier, diagnosticians are still left with the additional complication of the required extraction of viral RNA prior to PCR. Eliminating this step would significantly lower reagent costs per test, while also improving assay turnaround times, particularly when processing thousands of test samples. This second complication has also been resolved successfully with an improved device, GTR-STMdk.

Based on feedback from CLIA-lab partners, the "direct-into-PCR" product GTR-STMdk, eliminates the crucial 60 minute- pre-extraction and RNA amplification step. This is a significant advance as it saves up to $25 \%$ of workflow process time and reduces the added costs of non-PCR reagents. The key difference between GTR-STM and GTR-STMdk is the addition of Proteinase $\mathrm{K}$ pre-dried along with the RNA stabilization chemistry. Proteinase $\mathrm{K}$ degrades the viral coat, releasing the RNA and therefore eliminating the need of pre-extraction for RNA amplification.

The following experiments were performed with gamma-irradiated SARS-CoV-2 virus spiked saliva samples kept in GTR-STMdk, where the focus was to push the COVID-19 testing envelope in terms of improving process workflow and reagent cost efficiencies and increased sensitivity of SAR-CoV-2 detection. All experiments were conducted with clinically realistic low levels of SARS-CoV-2 spiked into saliva of $0.4 \mathrm{geq} / \mathrm{uL}$ and $2.0 \mathrm{geq} / \mathrm{uL}$.

Figure 7 demonstrates the effect of sample and reaction volumes on RT-PCR data using GTRSTMdk, an important consideration pointed out by CLIA lab partners. Since reagents account for one third of lab test costs, any reduction in total reaction volume used during the RT-PCR step, particularly when millions of samples are assayed, would yield substantial cost savings in 
testing.

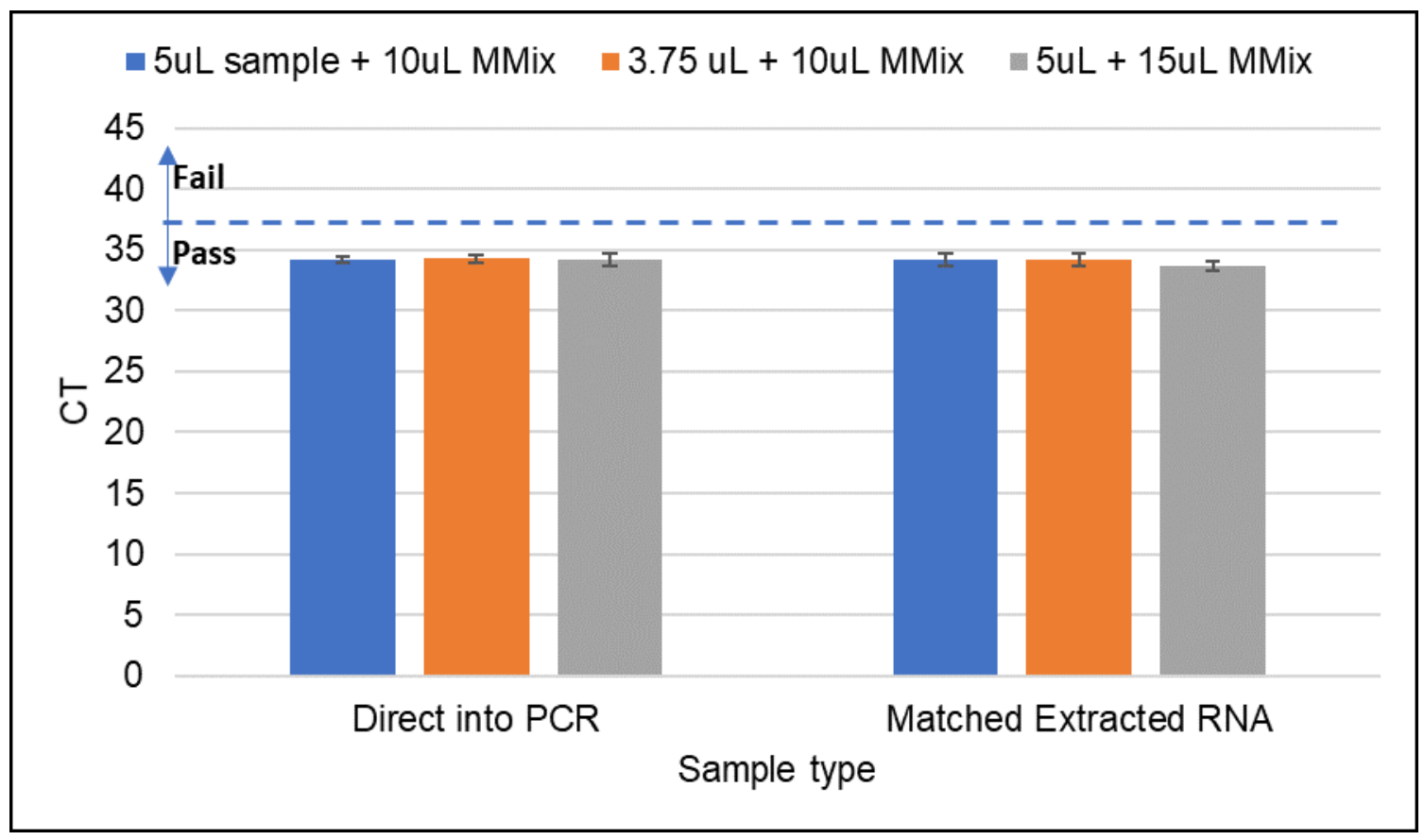

Figure 7: GTR-STMdk Sample Volume Titration in RT-PCR. 500uL of saliva spiked with 2.0 geq/uL of gamma-irradiated SARS-CoV-2 virus added to GTR-STMdk was incubated at $56^{\circ} \mathrm{C}$ for 5 minutes followed by $95^{\circ} \mathrm{C}$ for 5 minutes. Direct into PCR was performed with 3.75uL to 5.OuL of GTRSTMdk sample added to 10uL to 15uL of mastermix and amplified with CDC's N1 primer. The pass/fail criteria set to Matched Extracted RNA samples at 37.2 CT.

\section{Study setup}

500uL of saliva contrived with gamma-irradiated SARS-CoV-2 virus, 2 geq /uL, was added to GTR-STMdk device. Six replicates each with; (i) 5uL of sample to $10 \mathrm{uL}$ of TaqPath RT-PCR master mix, (ii) 3.75uL of sample to $10 \mathrm{uL}$ of master mix, (iii) $5 \mathrm{uL}$ of sample to $15 \mathrm{uL}$ of master mix (ThermoFisher volume).

Experimental Samples were added directly into the RT-PCR assay after first heating for five minutes at $56^{\circ} \mathrm{C}$, followed by 15 minutes at $95^{\circ} \mathrm{C}$, and then cooling for 5 minutes at $4^{\circ} \mathrm{C}$ ("Direct into PCR" in Figure 8).

Control Samples were extracted with QIAamp viral RNA kit from 100uL of saliva sample. The extracted RNA was eluted in 100uL of Elution Buffer (CT, STMdk Extracted), then subjected to RT-PCR ('Matched Extracted RNA' in Figure 7)

Quantification: 3.75uL to 5uL of RNA was quantified with CDC's SARS-CoV-2 RT-qPCR assay for $\mathrm{N} 1$ primer. 
The results show that similar CT values were obtained using a total RT-PCR volume of 13.75uL comprising 3.75uL test sample and $10 \mathrm{uL}$ of reagent master mix versus $20 \mathrm{uL}$ comprising $5 \mathrm{uL}$ test sample versus $15 \mathrm{uL}$ reagent master mix. Thus, potential savings in reagent costs of up to $30 \%$ could be realized using GTR-STMdk.

The practical utility of the GTR-STMdk device was further explored to account for variable volumes of saliva samples collected on site. COVID-19 patients may experience difficulties in generating sufficient saliva volumes due to their weakened condition. Figure 8 shows RT-PCR data in which contrived saliva sample volumes of $50 \mathrm{uL}, 100 \mathrm{uL}, 500 \mathrm{uL}$ and $1,000 \mathrm{uL}$ were placed inside GTR-STMdk devices.

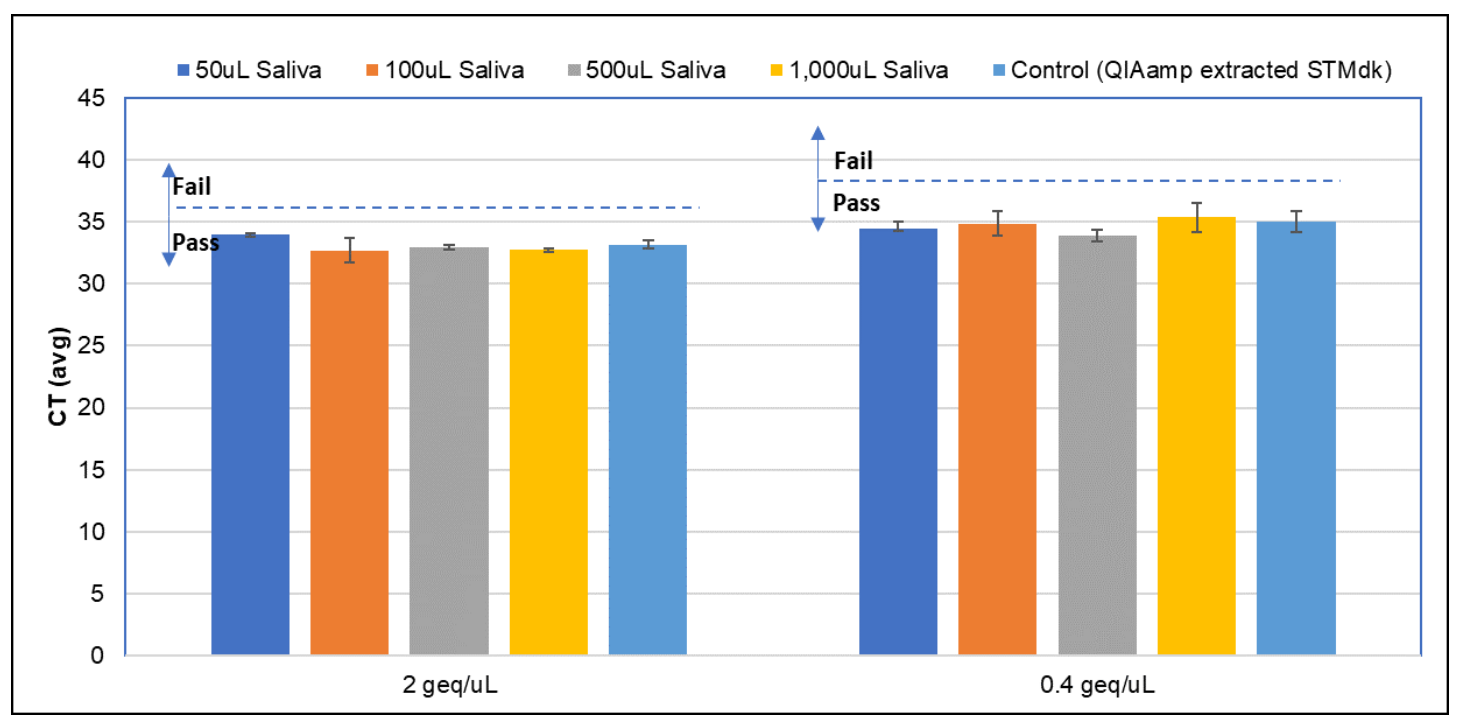

Figure 8: Saliva Volume Titration in GTR-STMdk. Various volumes (50uL to $1 \mathrm{~mL}$ ) of saliva, spiked with gamma-irradiated SARS-CoV-2 virus (BEI Resources) at 0.4 genome equivalents/uL (Right Panel) or 2.0 genome equivalents/uL (Left Panel), were kept in GTR-STMdk before direct RT-PCR assay. The pass/fail criteria are set to the QIAamp extracted STMdk control samples for $2.0 \mathrm{geq} / \mathrm{uL}$ panel and 0.4geq/uL and is 36 and $38 \mathrm{CT}$ values respectively.

\section{Study setup}

Various volumes, 50uL, 100uL, 500uL and 1,000uL of Contrived Saliva at $0.4 \mathrm{geq} / \mathrm{uL}$ and 2.0 geq/uL of gamma-irradiated SARS-CoV-2 (BEI Resources) added to STMdk devices.

Experimental Samples were heated for 5 minutes at $56^{\circ} \mathrm{C}$, then heated for 5 minutes at $95^{\circ} \mathrm{C}$, cooled for 5 minutes at $4^{\circ} \mathrm{C}$, then subjected to direct RT-PCR.

Control Samples were extracted with QIAamp viral RNA kit from 100uL of saliva sample. The extracted RNA was eluted in 100uL of Elution Buffer (CT, STMdk Extracted). 
Quantification: 5uL of RNA was quantified with CDC's SARS-CoV-2 RT-qPCR assay for N1 primer.

At both the low and high doses of SARS-CoV-2, samples at all saliva volumes tested gave CT values below the "Pass/Fail" criterion. Therefore, the GTR-STMdk device would be suitable for use with saliva sample volumes as low as $50 \mathrm{uL}$ and as high as $1 \mathrm{~mL}$.

Also, compared to the samples in Figure 7, the direct to PCR samples in Figure 8 were heated for 15 minutes at $95^{\circ} \mathrm{C}$ without first being heated at $56^{\circ} \mathrm{C}$ for five minutes. The elimination of the $56^{\circ} \mathrm{C}$ step had no impact on CT "Pass/Fail" results at both SARS-CoV-2 virus levels - $0.4 \mathrm{geq} / \mathrm{uL}$ and $2.0 \mathrm{geq} / \mathrm{uL}$.

As shown in the process workflow chart in the Introduction in Figure 1, in a typical clinical lab situation, so long as the saliva samples in GTR-STMdk are kept at ambient temperature for one hour before processing, only the $95^{\circ} \mathrm{C}$ heating step would be required. The $56^{\circ} \mathrm{C}$ step may be needed in a point of care diagnostic situation when saliva is collected and processed immediately.

Figure 9 shows RT-PCR data of saliva samples spiked with gamma-irradiated SARS-CoV-2 at 0.4 geq/uL (Panel A) and 2 geq/uL (Panel B) in the direct-to-PCR GTR-STMdk device, with NO pre-extraction or -amplification. The samples were further assayed on days 1, 2 and 3 following storage at ambient temperature.

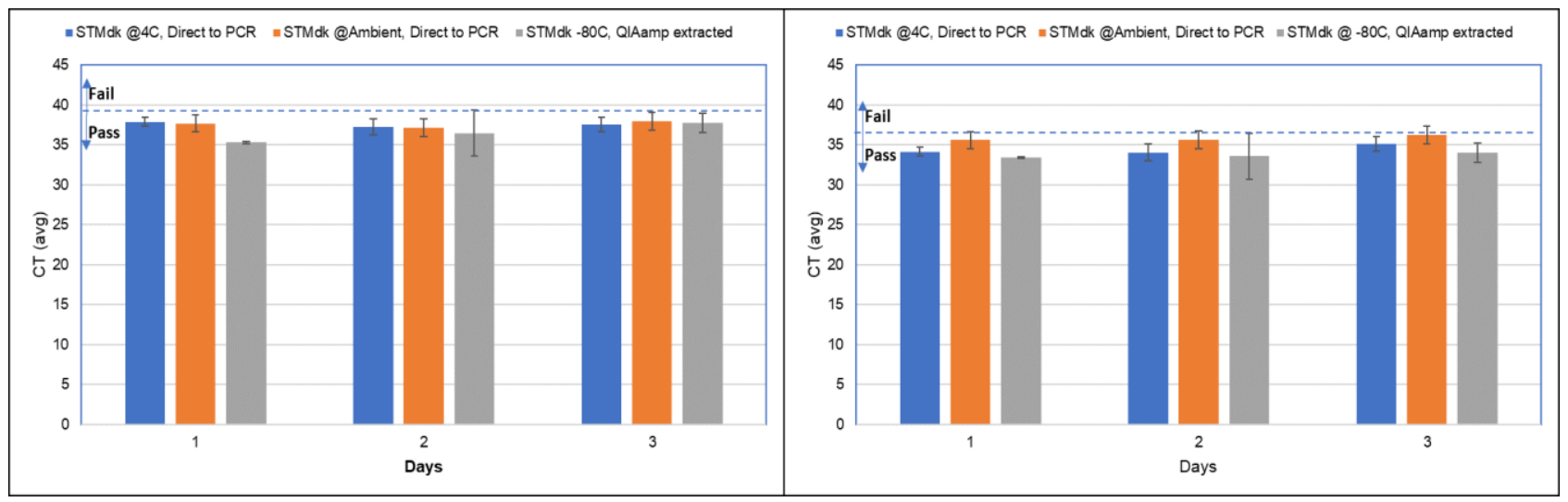

Figure 9: Stability of Saliva-spiked gamma-irradiated SARS CoV-2 virus in GTR-

STMdk ${ }^{\mathrm{TM}}$ at $25^{\circ} \mathrm{C}$. Gamma-irradiated SARS-CoV-2 virus (BEI Resources) at 0.4 genome equivalents/uL (Left Pane A) or 2.0 genome equivalents/uL (Right Panel B) was spiked in 500uL of saliva kept in GTR-STMdk, and stored at $4{ }^{\circ} \mathrm{C}, 25^{\circ} \mathrm{C}$, or $-80^{\circ} \mathrm{C}$ for up to three days before direct $R T$ PCR assay.

\section{Study setup}


medRxiv preprint doi: https://doi.org/10.1101/2021.01.20.20243782; this version posted January 25, 2021. The copyright holder for this preprint (which was not certified by peer review) is the author/funder, who has granted medRxiv a license to display the preprint in perpetuity.

All rights reserved. No reuse allowed without permission.

Experimental Sample: $500 \mathrm{uL}$ of Contrived Saliva at $0.4 \mathrm{geq} / \mathrm{uL}$ and $2.0 \mathrm{geq} / \mathrm{uL}$ of gammairradiated SARS-CoV-2 (BEI Resources) added to STMdk devices. They were stored at $4^{\circ} \mathrm{C}$ and $25^{\circ} \mathrm{C}$.

Control Sample: Two controls were set up in this experiment. One for direct into PCR was placed at $4^{\circ} \mathrm{C}$ in order to keep the Proteinase $\mathrm{K}$ active under ideal conditions and another set of controls for determining the amount of viral RNA that is to be expected for the direct into PCR sample. The later was determined by extraction of the viral RNA from this sample with QIAamp viral RNA kit (true control). Controls are 500uL of Contrived Saliva at $0.4 \mathrm{geq} / \mathrm{uL}$ and $2.0 \mathrm{geq} / \mathrm{uL}$ of SARS-CoV-2 (BEI Resources) added to STMdk devices. QIAamp extraction of viral RNA was from $100 \mathrm{uL}$ of $-80^{\circ} \mathrm{C}$ control saliva samples and eluted with $100 \mathrm{uL}$ of elution buffer.

Sample Treatment: 50uL aliquots from each experimental and control sample were withdrawn on days 1,2 and 3 , heated for 15 minutes at $95^{\circ} \mathrm{C}$, cooled for 5 minutes at $4^{\circ} \mathrm{C}$, then subjected to RT-PCR

Quantification: 5uL of RNA was quantified with CDC's SARS-CoV-2 RT-qPCR assay for N1 primer.

At both the low and high doses of SARS-CoV-2, all samples gave CT values below the "Pass/Fail" criterion up to three days. Saliva samples contrived with heat inactivated or gamma-irradiated virus kept in GTR-STMdk beyond three days at $25^{\circ} \mathrm{C}$ had $\mathrm{CT}$ values above the "Pass/Fail" threshold.

Independent studies by an external collaborator with SARS-CoV-2 infected clinical samples from COVID-19 patients collected in GTR-STMdk have demonstrated stability of the SARSCoV-2-viral RNA for up to nine days at $4{ }^{\circ} \mathrm{C}$ (data not shown). Therefore, the GTR-STMdk device is ideally suited for sample collection at testing sites, such as clinical labs, where the device can be quickly refrigerated following saliva sample collection. 
medRxiv preprint doi: https://doi.org/10.1101/2021.01.20.20243782; this version posted January 25, 2021. The copyright holder for this preprint (which was not certified by peer review) is the author/funder, who has granted medRxiv a license to display the preprint in perpetuity.

All rights reserved. No reuse allowed without permission.

\section{Discussion and Concluding Remarks}

Many countries, including US, are still in the grips of the COVID-19 pandemic while other countries are experiencing a resurgence or a potential second wave. Mass screening for the presence of SARS-CoV-2 in the general population has become an imperative. GTR-STM and GTR-STMdk provide essential technological advances in COVID-19 testing, by enhancing the ease of sample collection, increasing assay sensitivity, improving safety and facilitating lab workflow while enabling lower costs and faster turnaround times.

Saliva sampling is a safer, more convenient and practical alternative to nasopharyngeal swabs. GenTegra has been on the forefront of developing dried-media sample collection devices for a variety of testing applications, and this technology has been logically extended to develop two non-dilutive saliva collection products, GenTegra GTR-STM and GTR-STMdk. GenTegra's proprietary Active Chemical Protection chemistry is particularly applicable to SARs-CoV-2 PCR assays where prevention of RNA degradation and preservation of stability during transport from sample collection to lab test sites is essential to ensuring high test accuracy and sensitivity.

GTR-STM, while a simple device, has the following attributes: (i) direct collection of saliva by expectoration into a tube containing dried stabilizers to avoid sample dilution, (ii) use of stabilizers that are generally known to inactivate infectious virus, and (iii) SARS-CoV-2 stability for up to 60 days at ambient temperature. At the test site, the viral RNA in the sample would need to be extracted and amplified before PCR analysis. Due to its ability to retain viral RNA stability for several weeks at ambient temperature, GTR-STM would be ideally suited for home-based sample collection after which the sample containing devices may be shipped and transported worldwide at temperatures up to $56^{\circ} \mathrm{C}$ to authorized CLIA labs..

GTR-STMdk incorporates Proteinase K into the saliva sample collection device itself, eliminating the Proteinase $\mathrm{K}$ addition step at the testing site, which reduces potential avenues for error. In addition, the sample can be directly subjected to RT-PCR without the need for RNA pre-amplification. The benefit of NOT requiring RNA extraction and amplification at the test site provides a substantial improvement to throughput by reducing test turnaround times. In SARS-CoV-2 spiked saliva samples collected in GTR-STMdk, virus levels down to 0.4 geq/uL can be detected using as little as $3.75 \mathrm{uL}$ of sample volume and $30 \%$ less quantity of expensive PCR assay reagents. The device is also effective with saliva collection volumes as low as $0.05 \mathrm{~mL}$, minimizing difficulty for patients struggling to provide a usable sample when under stress. GTR-STMdk is ideally suited for sample collection at locations proximal to 
the testing site as it requires sample storage at $4^{\circ} \mathrm{C}$. Storage of GTR-STMdk saliva samples at the testing site at $4^{\circ} \mathrm{C}$ extends stability up to nine days (confidential personal communication from a CLIA partner, data not shown).

A comparison of the characteristics and utility of the two devices is given in Table 1.

\begin{tabular}{|c|c|c|}
\hline \multicolumn{3}{|c|}{ GTR-STM and GTR-STMdk Specifications } \\
\hline \multicolumn{3}{|c|}{ Collection and Storage Parameters } \\
\hline Saliva Sample Collection & At Home or On Site & On Site \\
\hline Volume of Saliva & $1 \mathrm{~mL}$ to $2 \mathrm{~mL}$ & $50 \mathrm{uL}$ to $1 \mathrm{~mL}$ \\
\hline SARS-CoV-2 Stability, Ambient & 60 Days & 3 Days \\
\hline Saliva Sample Storage & Ambient & Ambient \\
\hline Product Stability & One Year & One Year \\
\hline RT-PCR Assay Process Parameters \\
\hline RNA extraction & YES & NO \\
\hline Direct into PCR & NO & YES \\
\hline Addition of Proteinase K & N/A & NO \\
\hline Sample Volume Required for RT-PCR & 3.75 uL to 5.00uL & 3.75 uL to 5.00uL \\
\hline Lab RT-PCR Processing Time & 4 Hours & 3 Hours \\
\hline
\end{tabular}

Table 1: GTR-STM and GTR-STMdk Specifications.

Table 2 provides a comparison of the attributes of GTR-STM and GTR-STMdk to other saliva collection products currently marketed. 


\begin{tabular}{|c|c|c|c|c|c|c|c|c|c|c|}
\hline $\begin{array}{l}\stackrel{N}{\vec{u}} \\
\text { ్ㅗ } \\
\underline{\underline{n}}\end{array}$ & 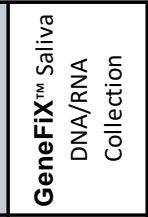 & $\stackrel{\breve{~}}{\rightleftharpoons}$ & z & $\stackrel{\breve{~}}{\rightleftharpoons}$ & z & q & 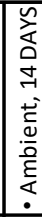 & & $\sum$ & 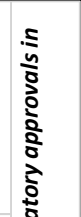 \\
\hline 峞 & 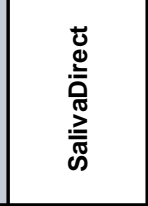 & $\stackrel{\breve{्}}{\boldsymbol{~}}$ & z & z & $\stackrel{\breve{్}}{>}$ & $\stackrel{\breve{\nu}}{\nu}$ & 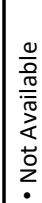 & & 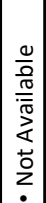 & 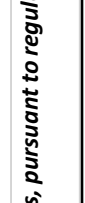 \\
\hline$\sum_{i}^{O}$ & 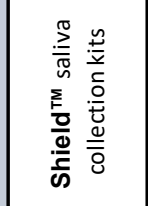 & $\stackrel{\breve{山}}{=}$ & $\frac{1}{z}$ & 2 & z & 2 & 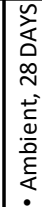 & & $\Sigma$ & 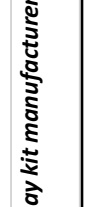 \\
\hline 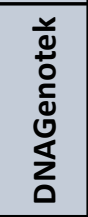 & 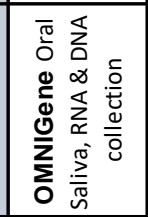 & $\stackrel{\breve{~}}{\rightleftharpoons}$ & २ & $\stackrel{\breve{~}}{\rightleftharpoons}$ & 2 & श & 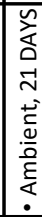 & & $\frac{\pi}{z}$ & 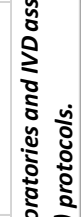 \\
\hline 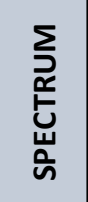 & $\begin{array}{l}\frac{8}{0} \\
\frac{1}{2} \\
\text { ô }\end{array}$ & 亗 & z & $\stackrel{\breve{्}}{\boldsymbol{\nu}}$ & 2 & ? & 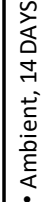 & & 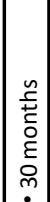 & 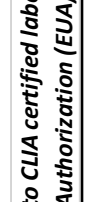 \\
\hline 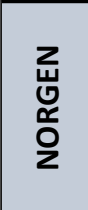 & 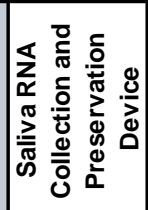 & 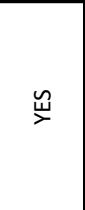 & q & $\stackrel{\breve{्}}{\boldsymbol{\nu}}$ & q & ? & 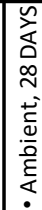 & & 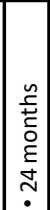 & 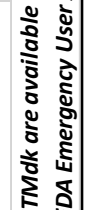 \\
\hline $\begin{array}{l}0 \\
\frac{0}{0} \\
\frac{0}{5} \\
\text { ป }\end{array}$ & 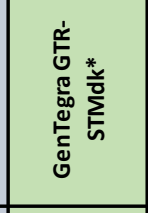 & 2 & $\stackrel{\mathscr{m}}{\rightleftharpoons}$ & 을 & $\stackrel{\oiiint}{\rightleftharpoons}$ & $\stackrel{\leftrightarrow}{\rightleftarrows}$ & 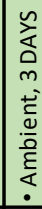 & & 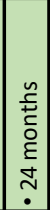 & 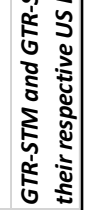 \\
\hline $\begin{array}{l}5 \\
\text { ธัँ } \\
\frac{8}{5}\end{array}$ & 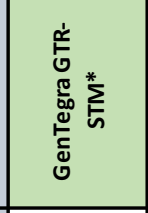 & 2 & 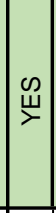 & $\stackrel{\mathscr{W}}{\rightleftharpoons}$ & o) & \% & 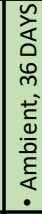 & 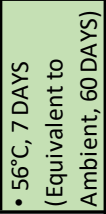 & 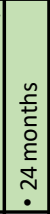 & 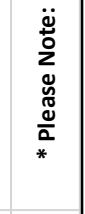 \\
\hline 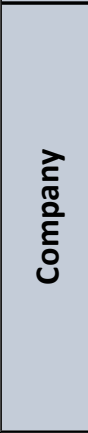 & $\begin{array}{l}\frac{U}{\mathrm{U}} \\
\overline{0} \\
\stackrel{0}{0}\end{array}$ & 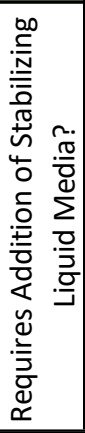 & 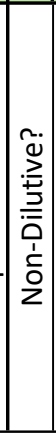 & 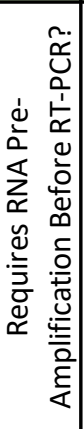 & 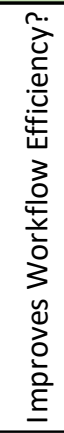 & 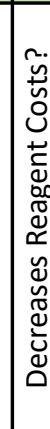 & 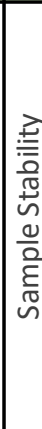 & & 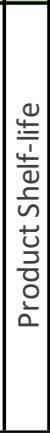 & \\
\hline
\end{tabular}

Table 2: GTR-STM and GTR-STMdk comparative saliva collection devices. 
In this report, the saliva used was from a commercially available source. Studies are in progress in GenTegra labs as well in collaboration with CLIA lab partners to confirm these data using individual human saliva samples. We have provided a conservative estimate for assay sensitivity, pending a more formal determination of test Limit of Detection (LoD) for samples collected in GTR-STM and GTR-STMdk.

The switch to dry chemical saliva sample collection devices GTR-STM and GTR-STMdk, can achieve significant improvements in SARS-CoV-2 RT-PCR testing throughput efficiencies. Saliva sampling with GTR devices also greatly enhances patient convenience, safety, reduces testing costs and reporting times for test results. The enhancement to accuracy, sensitivity and PCR assay turnaround times using GTR devices can greatly expand the number of asymptomatic individuals that can be tested on a regular basis while facilitating testing on pooled samples. The numerous sample testing advances provided by GTR devices are essential to support COVID-19 testing for all, with the ultimate critical goal to better control the ongoing pandemic until a safe and efficacious viral vaccine and therapies becomes widely available.

\section{Abbreviations}

COVID-19, Coronavirus Disease 19

SARS-CoV-2, Severe Acute Respiratory Syndrome Coronavirus 2

RT-PCR, Reverse Transcriptase-Polymerase Chain Reaction

PCR, Polymerase Chain Reaction

ANCOVA, Analysis of covariance

GTR-VTM, GenTegra Viral Transport Medium

GTR-STM, GenTegra Saliva Transport Medium

GTR-STMdk, GenTegra Saliva Transport Medium Direct Proteinase K ACP, Active Chemical Protection 
medRxiv preprint doi: https://doi.org/10.1101/2021.01.20.20243782; this version posted January 25, 2021. The copyright holder for this preprint

(which was not certified by peer review) is the author/funder, who has granted medRxiv a license to display the preprint in perpetuity.

All rights reserved. No reuse allowed without permission.

CLIA, Clinical Laboratory Improvements Act (1984)

RNA, Ribonucleic Acid

uL, Microliter

$\mathrm{mL}$, Milliliter

geq/uL, Genome Equivalents per microliter

LoD, Limit of Detection

NP, Nasopharyngeal

CT, Cycle Threshold

CDC, Centers for Disease Control, Atlanta, GA

Rnase, Ribonuclease

MMix, Master mix 
medRxiv preprint doi: https://doi.org/10.1101/2021.01.20.20243782; this version posted January 25, 2021. The copyright holder for this preprint (which was not certified by peer review) is the author/funder, who has granted medRxiv a license to display the preprint in perpetuity.

\section{Materials and Methods}

Study setup for each set of experiments is given in the respective legend below each Figure.

Neat saliva samples were prepared by contriving commercially purchased saliva, (Lee BioSolutions, cat \#991-05-P-250) with SARS-CoV-2 virus to the desired concentration. Heat-

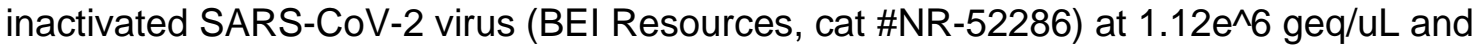
gamma-irradiated virus (BEI Resources, cat \#NR-52287) at $1.7 \mathrm{e}^{\wedge} 6 \mathrm{geq} / \mathrm{uL}$. Unless otherwise stated in the respective Figure, a total of $1000 \mathrm{uL}$ of contrived saliva was added to GTR-STM tubes and $500 \mathrm{uL}$ of contrived saliva was added to GTR-STMdk tubes. GTR-STM tubes were gently mixed at room temperature for 5 minutes or until the pellet had gone completely into solution. GTR-STMdk tubes were allowed sit for 1 hour at room temperature.

GTR-STM was tested by extraction with either QIAamp Viral RNA Mini Kit (Qiagen, cat \#52906) or MagMAX Viral RNA Isolation Kit (ThermoFisher, cat \#AM1939) and compared with either PBS or neat saliva as controls. Samples extracted with QIAamp Viral RNA Mini Kit always contained either 50 or $100 \mathrm{uL}$ of sample volume and were normalized by eluting in either 50 or $100 \mathrm{uL}$ of elution buffer, depending on the sample volume. Samples extracted with MagMAX Viral RNA Isolation Kit followed a modified protocol and always contained $200 \mathrm{uL}$ of sample volume and were eluted in $50 \mathrm{uL}$ of elution buffer. The eluted viral RNA was then quantified with RT-qPCR (see below).

Two different heating methods were tested with contrived saliva in GTR-STMdk. First, samples were heated at $56^{\circ} \mathrm{C}$ for 5 minutes, before being heated at $95^{\circ} \mathrm{C}$ for 5 minutes. The second method tested was heating at $95^{\circ} \mathrm{C}$ for 15 minutes to deactivate the Proteinase $\mathrm{K}$ in the solution. The second method was sufficient in deactivating the Proteinase $\mathrm{K}$ before RT-qPCR and provided similar results to the first method, so the $56^{\circ} \mathrm{C}$ for 5 minutes step was removed.

Viral RNA samples from contrived saliva in GTR-STM and contrived saliva in GTR-STMdk were both quantified with RT-qPCR using a StepOnePlus ${ }^{\text {TM }}$ Real Time PCR System (ThermoFisher Scientific). Samples were prepared, according to the CDC 2019-Novel Coronavirus (2019-nCoV) Real-Time RT-PCR Diagnostic Panel, by mixing 5 uL of viral RNA with 3.5 or 5 uL of TaqPath ${ }^{\text {TM }}$ 1-Step RT-qPCR Master Mix, CG (ThermoFisher, cat \#A15299), 8.5 uL of HyPure ${ }^{\mathrm{TM}}$ Molecular Biology Grade Water (HyClone ${ }^{\mathrm{TM}}$, cat \#SH30538.03), and 1.5 uL of CDC combined primer/probe mix (Integrated DNA Technologies, cat \#10006713). CDC primer/probe mix includes N1, N2, and RNASEP. Samples were plated in triplicates into a 96- 
medRxiv preprint doi: https://doi.org/10.1101/2021.01.20.20243782; this version posted January 25, 2021. The copyright holder for this preprint (which was not certified by peer review) is the author/funder, who has granted medRxiv a license to display the preprint in perpetuity.

All rights reserved. No reuse allowed without permission.

well plate. Thermocycler conditions consisted of 2 minutes at $25^{\circ} \mathrm{C}, 15$ minutes at $50^{\circ} \mathrm{C}, 95^{\circ} \mathrm{C}$ at 2 minutes, and 45 cycles of $95^{\circ} \mathrm{C}$ at 3 seconds and $55^{\circ} \mathrm{C}$ at 30 seconds.

Criteria for determination of SARS-CoV-2 positivity in RT-PCR Assay: Based on FDA guidance, samples were considered positive if the CT value was less than the "Pass/Fail" criterion of Mean CT + 3CT, and negative if above the "Pass/Fail" criterion. 
medRxiv preprint doi: https://doi.org/10.1101/2021.01.20.20243782; this version posted January 25, 2021. The copyright holder for this preprint (which was not certified by peer review) is the author/funder, who has granted medRxiv a license to display the preprint in perpetuity.

All rights reserved. No reuse allowed without permission.

\section{References}

1. https://www.nbcnewyork.com/tag/coronavirus-pandemic/

2. Lai CC, Wang CY, Wang YH, Hsueh SC, Ko WC, Hsueh PR. Global epidemiology of coronavirus disease 2019 (COVID-19): disease incidence, daily cumulative index, mortality, and their association with country healthcare resources and economic status. Int $\mathrm{J}$ Antimicrob Agents. 2020 Apr;55(4):105946. doi: 10.1016/j.ijantimicag.2020.105946.

3. Lai CC, Wang CY, Wang YH, Hsueh PR. Global coronavirus disease 2019: What has daily cumulative index taught us? Int J Antimicrob Agents. 2020 Jun;55(6):106001. doi: 10.1016/j.ijantimicag.2020.106001.

4. Keeling MJ, Hollingsworth TD, Read JM. Efficacy of contact tracing for the containment of the 2019 novel coronavirus (COVID-19). J Epidemiol Community Health. 2020 Oct;74(10):861-866. doi: 10.1136/jech-2020-214051.

5. Hellewell J, Abbott S, Gimma A, Bosse NI, Jarvis CI, Russell TW, Munday JD, Kucharski AJ, Edmunds WJ; Centre for the Mathematical Modelling of Infectious Diseases COVID-19 Working Group, Funk S, Eggo RM. Feasibility of controlling COVID-19 outbreaks by isolation of cases and contacts. Lancet Glob Health. 2020 Apr;8(4):e488-e496. doi: 10.1016/S2214-109X(20)30074-7.

6. Kucharski AJ, Klepac P, Conlan AJK, Kissler SM, Tang ML, Fry H, Gog JR, Edmunds WJ; CMMID COVID-19 working group. Effectiveness of isolation, testing, contact tracing, and physical distancing on reducing transmission of SARS-CoV-2 in different settings: a mathematical modelling study. Lancet Infect Dis. 2020 Oct;20(10):1151-1160. doi: 10.1016/S1473-3099(20)30457-6.

7. Kinoshita R, Anzai A, Jung SM, Linton NM, Miyama T, Kobayashi T, Hayashi K, Suzuki A, Yang Y, Akhmetzhanov AR, Nishiura H. Containment, Contact Tracing and Asymptomatic Transmission of Novel Coronavirus Disease (COVID-19): A Modelling Study. J Clin Med. 2020 Sep 27;9(10):3125. doi: 10.3390/jcm9103125.

8. Esbin MN, Whitney ON, Chong S, Maurer A, Darzacq X, Tjian R. Overcoming the bottleneck to widespread testing: a rapid review of nucleic acid testing approaches for COVID-19 detection. RNA. 2020 Jul;26(7):771-783. doi: 10.1261/rna.076232.120.

9. Touma M. COVID-19: molecular diagnostics overview. J Mol Med (Berl). 2020 Jul;98(7):947-954. doi: 10.1007/s00109-020-01931-w.

10. Burbelo PD, Riedo FX, Morishima C, Rawlings S, Smith D, Das S, Strich JR, Chertow DS, Davey RT, Cohen Jl. Sensitivity in Detection of Antibodies to Nucleocapsid and Spike Proteins of Severe Acute Respiratory Syndrome Coronavirus 2 in Patients With 
Coronavirus Disease 2019. J Infect Dis. 2020 Jun 29;222(2):206-213. doi:

10.1093/infdis/jiaa273.

11. Burbelo PD, Riedo FX, Morishima C, Rawlings S, Smith D, Das S, Strich JR, Chertow DS, Davey RT Jr, Cohen JI. Detection of Nucleocapsid Antibody to SARS-CoV-2 is More Sensitive than Antibody to Spike Protein in COVID-19 Patients. medRxiv [Preprint]. 2020 Apr 24:2020.04.20.20071423. doi: 10.1101/2020.04.20.20071423.

12. Deeks JJ, Dinnes J, Takwoingi Y, Davenport C, Spijker R, Taylor-Phillips S, Adriano A, Beese S, Dretzke J, Ferrante di Ruffano L, Harris IM, Price MJ, Dittrich S, Emperador D, Hooft L, Leeflang MM, Van den Bruel A; Cochrane COVID-19 Diagnostic Test Accuracy Group. Antibody tests for identification of current and past infection with SARS-CoV-2. Cochrane Database Syst Rev. 2020 Jun 25;6(6):CD013652. doi:

10.1002/14651858.CD013652.

13. Interim Guidelines for Collecting, Handling, and Testing Clinical Specimens from Persons for Coronavirus Disease 2019 (COVID-19) [Accessed March 22, 2020]. Available at: https://www.cdc.gov/coronavirus/2019-nCoV/lab/guidelines-clinical-specimens.html.

14. Takeuchi Y, Furuchi M, Kamimoto A, Honda K, Matsumura H, Kobayashi R. Saliva-based PCR tests for SARS-CoV-2 detection. J Oral Sci. 2020;62(3):350-351. doi:

10.2334/josnusd.20-0267.

15. Lahner E, Dilaghi E, Prestigiacomo C, Alessio G, Marcellini L, Simmaco M, Santino I, Orsi GB, Anibaldi P, Marcolongo A, Annibale B, Napoli C. Prevalence of Sars-Cov-2 Infection in Health Workers (HWs) and Diagnostic Test Performance: The Experience of a Teaching Hospital in Central Italy. Int J Environ Res Public Health. 2020 Jun 19;17(12):4417. doi: 10.3390/ijerph17124417.

16. Zitek T. The Appropriate Use of Testing for COVID-19. West J Emerg Med. 2020 Apr 13;21(3):470-472. doi: 10.5811/westjem.2020.4.47370.

17. Péré H, Podglajen I, Wack M, Flamarion E, Mirault T, Goudot G, Hauw-Berlemont C, Le L, Caudron E, Carrabin S, Rodary J, Ribeyre T, Bélec L, Veyer D. Nasal Swab Sampling for SARS-CoV-2: a Convenient Alternative in Times of Nasopharyngeal Swab Shortage. J Clin Microbiol. 2020 May 26;58(6):e00721-20. doi: 10.1128/JCM.00721-20.

18. Garcia Godoy LR, Jones AE, Anderson TN, Fisher CL, Seeley KML, Beeson EA, Zane HK, Peterson JW, Sullivan PD. Facial protection for healthcare workers during pandemics: a scoping review. BMJ Glob Health. 2020 May;5(5):e002553. doi: 10.1136/bmjgh-2020002553. 
medRxiv preprint doi: https://doi.org/10.1101/2021.01.20.20243782; this version posted January 25, 2021. The copyright holder for this preprint (which was not certified by peer review) is the author/funder, who has granted medRxiv a license to display the preprint in perpetuity.

All rights reserved. No reuse allowed without permission.

19. Procop GW, Shrestha NK, Vogel S, Van Sickle K, Harrington S, Rhoads DD, Rubin BP, Terpeluk P. A Direct Comparison of Enhanced Saliva to Nasopharyngeal Swab for the Detection of SARS-CoV-2 in Symptomatic Patients. J Clin Microbiol. 2020 Oct 21;58(11):e01946-20. doi: 10.1128/JCM.01946-20.

20. Hanson KE, Barker AP, Hillyard DR, Gilmore N, Barrett JW, Orlandi RR, Shakir SM. SelfCollected Anterior Nasal and Saliva Specimens versus Health Care Worker-Collected Nasopharyngeal Swabs for the Molecular Detection of SARS-CoV-2. J Clin Microbiol. 2020 Oct 21;58(11):e01824-20. doi: 10.1128/JCM.01824-20.

21. Hung KF, Sun YC, Chen BH, Lo JF, Cheng CM, Chen CY, Wu CH, Kao SY. New COVID19 saliva-based test: How good is it compared with the current nasopharyngeal or throat swab test? J Chin Med Assoc. 2020 Oct;83(10):891-894. doi:

10.1097/JCMA.0000000000000396.

22. Yee R, Truong T, Pannaraj PS, Eubanks N, Gai E, Jumarang J, Turner L, Peralta A, Lee Y, Bard JD. Saliva is a promising alternative specimen for the detection of SARS-CoV-2 in children and adults. medRxiv [Preprint]. 2020 Oct 27:2020.10.25.20219055. doi: 10.1101/2020.10.25.20219055.

23. https://www.fda.gov/news-events/press-announcements/coronavirus-covid-19-update-fdaauthorizes-first-diagnostic-test-using-home-collection-saliva

24. Persano, S., Vecchio, G. \& Pompa, P. A hybrid chimeric system for versatile and ultrasensitive RNase detection. Sci Rep 5, 9558 (2015). https://doi.org/10.1038/srep09558.

25. Darnell, M. E., Subbarao, K., Feinstone, S. M., \& Taylor, D. R. (2004). Inactivation of the 170 coronavirus that induces severe acute respiratory syndrome, SARS-CoV. Journal of virological171 methods, 121(1), 85-91. https://doi.org/10.1016/j.jviromet.2004.06.006.

26. Abraham JP, Plourde BD, Cheng L. Using heat to kill SARS-CoV-2. Rev Med Virol. 2020 Sep;30(5): e2115. doi: 10.1002/rmv. 